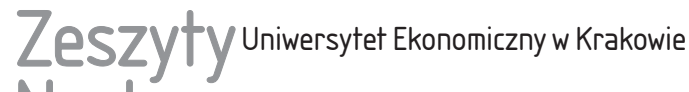 Naukowe
}

$4(940)$

ISSN 1898-6447

Zesz. Nauk. UEK, 2015; $4(940)$ : 35-44 DOI: 10.15678/ZNUEK.2015.0940.0403

\author{
Maria Jadamus-Hacura \\ Krystyna Melich-Iwanek \\ Katedra Ekonometrii \\ Uniwersytet Ekonomiczny w Katowicach
}

\section{Elastyczność polskiego rynku pracy - analiza dynamiczna}

\section{Streszczenie}

W artykule skupiono się na badaniu elastyczności polskiego rynku pracy w latach 2002-2012. Na wstępie omówione zostały pojęcie i rola deregulacji rynku pracy we współczesnej gospodarce. Przedmiotem zainteresowania było zbadanie skali oraz dynamiki elastyczności polskiego rynku pracy, którą opisywano za pomocą 10 wskaźników cząstkowych. Badanie przeprowadzono za pomocą trzech miar syntetycznych i porównywano zmiany ich wartości w czasie.

Słowa kluczowe: rynek pracy, elastyczność rynku pracy, zmienna syntetyczna, syntetyczne miary rozwoju.

\section{Wprowadzenie}

Jednym z głównych problemów współczesnych rynków pracy, nabierających szczególnego znaczenia w okresach spowolnienia bądź kryzysu gospodarczego, jest kwestia stopnia jego elastyczności. Zmieniająca się struktura produkcji, postęp techniczny, komputeryzacja i powszechność szeroko rozumianych technologii informatycznych, globalizacja, problemy społeczne itp. wymagają, a często i wymuszają wprowadzanie zmian w sposobie funkcjonowania i regulowania rynku pracy. Do działań ukierunkowanych na poprawę funkcjonowania tych rynków w rozwiniętych współczesnych gospodarkach należy między innymi częściowe ich deregulowanie. Skala owych deregulacji jest różna w poszczegól- 
nych krajach i zależy między innymi od ogólnej kondycji gospodarki, polityki społecznej, sytuacji i instytucji działających na rynku pracy, prawa pracy czy wreszcie szeroko rozumianej tradycji.

Przedmiotem artykułu jest zbadanie skali elastyczności polskiego rynku pracy oraz odpowiedź na pytanie, czy zmiany warunków gospodarowania, szczególnie w okresie spowolnienia wzrostu gospodarczego, znalazły odzwierciedlenie w postaci zmian w zasadach funkcjonowania rynku pracy. Badaniem objęto polski rynek pracy w latach 2002-2012.

\section{Elastyczność rynku pracy}

W sposób najbardziej ogólny elastyczność rynku można określić jako łatwość adaptowania się uczestników rynku pracy do zmieniających się warunków zewnętrznych i wewnętrznych. Na elastycznym rynku pracy pracownicy nie mają trudności ze znalezieniem nowej pracy, a pracodawcy ze zwalnianiem zbędnych pracowników lub z przyjmowaniem nowych. Przeciwieństwem rynku elastycznego jest rynek sztywny, na którym zmiana pracy jest bardzo utrudniona.

Stopień elastyczności rynku pracy, będącej skutkiem procesu jego deregulacji jest zależny przede wszystkim od przyjętych rozwiązań instytucjonalnych, polityki gospodarczej, struktury rynku pracy oraz kwalifikacji pracowników. Na elastycznym rynku obserwuje się zmiany charakteryzujące się „zwiększaniem swobody podmiotów gospodarczych i mniejszą ingerencją państwa w dziedzinie zbiorowych stosunków pracy" [Elastyczność polskiego rynku pracy 2004, s. 7]. Zmiany te dotyczą między innymi: systemu zabezpieczenia społecznego, regulacji w zakresie płacy minimalnej, ustawodawstwa dotyczącego ochrony stosunku pracy, uprawnień związków zawodowych.

W literaturze ekonomicznej wymienia się następujące elementy rynku pracy, które można określić jako elastyczności cząstkowe odnoszące się do: zatrudnienia, czasu pracy, płac, podaży pracy.

Elastyczność zatrudnienia, nazywana również numeryczną, oznacza zdolność przystosowywania się liczby zatrudnionych do zmieniających się warunków ekonomicznych. W tym aspekcie elastyczność oznacza nietypowe formy zatrudnienia między innymi takie, jak: kontrakty dotyczące konkretnego zadania, zatrudnienie na czas określony czy w niepełnym wymiarze czasu pracy, praca dorywcza lub na wezwanie, praca w domu, telepraca, dzielenie się pracą itp.

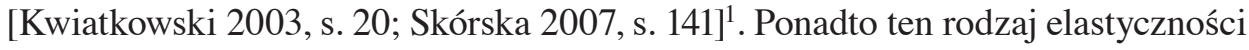
rynku pracy zależy od roli zysku w przedsiębiorstwie, stopnia ochrony stosunku pracy, kosztów przyjęć do pracy oraz zwolnień z pracy [Skórska 2007].

\footnotetext{
1 Problemom tym poświęcona jest m.in. praca: [Sobocka-Szczapa 2003].
} 
Elastyczność czasu pracy polega na różnorakich sposobach odchodzenia od standardowego czasu pracy, tj. w pełnym wymiarze, równomiernie rozłożonego w tygodniu, jednolitej liczby godzin pracy w ciągu dnia itd. Ta forma elastyczności rynku pracy to m.in.: praca w niepełnym wymiarze czasu pracy, ruchomy, indywidualny czas pracy w ciągu dnia, tygodnia, zmienny wymiar tygodniowego czasu pracy w zakładzie oraz uelastycznienie rocznego i realizowanego w ciągu całego życia zawodowego czasu pracy (w tym przypadku np. wcześniejsze przechodzenie na emeryturę) [Kwiatkowski 2003, s. 20; Skórska 2007, s. 137]. Elastyczny czas pracy powinien chronić pracowników przed zwolnieniami w okresach pogarszającej się koniunktury, umożliwiać zatrudnienie większej liczbie pracowników (wolumen pracy dzielony jest na większą liczbę osób) oraz pozwolić na podjęcie pracy tym spośród bezrobotnych, którzy nie są zainteresowani pracą według standardowego czasu pracy.

Elastyczność płac polega na ich wrażliwości na zmieniające się warunki na rynku pracy, zmiany rentowności przedsiębiorstwa i wydajności pracy. Giętkość lub sztywność płac zależy m.in. od: siły związków zawodowych (zainteresowanych raczej sztywnością płac), szczebla negocjowania i zawierania układów zbiorowych, strategii płacowych przedsiębiorstw oraz zakresu ingerencji państwa w kształtowanie płac, szczególnie płacy minimalnej [Kwiatkowski 2004, s. 21].

Elastyczność rynku pracy należy do tzw. zjawisk wielocechowych, zależy od wielu różnych czynników i przejawia się w wielu formach. Szczególne znaczenie ma jednak jej wyraz instytucjonalny. Do instytucjonalnych czynników wpływających na sytuację na rynku pracy należą [Góra 2003, Elastyczność polskiego rynku pracy 2004, s. 130-131]: ochrona zatrudnienia, opodatkowanie pracy, wysokość i okres, na który przyznawane są zasiłki dla bezrobotnych, siła przetargowa związków zawodowych, centralizacja/decentralizacja negocjacji płacowych.

Komentarza wymaga kwestia opodatkowania kosztów pracy. W praktyce występuje tzw. klin podatkowy rozumiany jako procentowy udział różnicy między całkowitym kosztem pracy a wynagrodzeniem netto pracownika w całkowitych kosztach pracy. Na klin podatkowy składają się m.in.: podatki pośrednie i bezpośrednie oraz parapodatki, wśród których istotną rolę odgrywają składki na ubezpieczenia społeczne [Góra 2003, s. 10; Ertman 2011]. Jest to jeden z czynników powodujących zakłócenia równowagi na rynku pracy, zwiększa bowiem koszty pracy dla pracodawców oraz zmniejsza wynagrodzenia dla pracowników. Skutkiem klina podatkowego jest ograniczenie zarówno podaży, jak i popytu na pracę, a to zwiększa bezrobocie, a także szarą strefę [Bartosik 2012, s. 35].

Kolejnym istotnym czynnikiem oddziałującym na elastyczność rynku pracy jest poziom tzw. stopy kompensacji, czyli stosunku wysokości zasiłków dla bezrobotnych do wynagrodzeń za pracę. Zbyt wysoka stopa kompensacji demobilizuje bezrobotnych do poszukiwania pracy. Ze względu na elastyczność rynku pracy 
zarówno klin podatkowy jak i stopa kompensacji powinny być stosunkowo niskie [Giegiel 2007, s. 13].

Rozważając determinanty rynku pracy, nie można pominąc roli związków zawodowych. Szczególnie dotyczy to stopnia uzwiązkowienia pracowników, ponieważ w warunkach silnej pozycji przetargowej związków zawodowych obserwuje się np. usztywnienie płac, zmniejszenie ich zróżnicowania, wzrost kosztów pracy itp.

Z rozważań teoretycznych i wyników badań empirycznych publikowanych w literaturze ekonomicznej wynika, że we współczesnych gospodarkach obserwuje się zmniejszające znaczenie związków zawodowych oraz zbiorowego prawa pracy na rzecz wzrostu znaczenia indywidualnego prawa pracy. Procesy te są zróżnicowane, zależne między innymi od stopnia integracji poszczególnych krajowych rynków z rynkiem światowym, od warunków lokalnych i tradycji ekonomicznych. Można zatem już mówić o ogólnej tendencji zmian w sposobie funkcjonowania współczesnych gospodarek.

\section{Założenia analizy elastyczności polskiego rynku pracy}

Kwestia elastyczności rynku pracy jest traktowana w literaturze jako jeden z najważniejszych problemów współczesnych gospodarek, w tym także polskiej. Na ostateczny wyraz elastyczności rynku pracy składa się wiele czynników i dlatego w celu badania tego problemu wykorzystano koncepcję analizy wielowymiarowej zaproponowaną przez A. Ertman [2011, s. 51-53]. W przywołanej pracy przedstawione zostały wyniki badania porównawczego elastyczności rynku pracy w wybranych krajach europejskich oraz w USA przeprowadzonego między innymi za pomocą metody TOPSIS (Technique for Order Preference by Similarity to an Ideal Solution) należącej do grupy porządkowania liniowego obiektów wielocechowych. Metoda ta jest pewnym rozwinięciem koncepcji obliczania taksonomicznej miary rozwoju Z. Hellwiga i dlatego równolegle przeprowadzono badania za pomocą tej procedury. Badanie przeprowadzono na podstawie danych pochodzących z lat 2002-2012.

Na procedurę obliczeniowa TOPSIS składają się następujące etapy:

- wybór (merytoryczny i formalny) indykatorów elastyczności rynku pracy. Wartości tych wskaźników, tworzą macierz o wymiarach $(m \times n)$ :

$$
\boldsymbol{X}=\left[x_{i t}\right],
$$

gdzie: $x_{i t}$ - wartość $i$-tego $(i=1,2, \ldots, m)$ wskaźnika elastyczności rynku pracy w roku $t, t=1,2, \ldots, n$;

- normalizacja wartości wybranych cech;

- dla stymulant 


$$
z_{i t}=\frac{x_{i t}-\min _{t} x_{i t}}{\max _{t} x_{i t}-\min _{t} x_{i t}} ;
$$

- dla destymulant

$$
z_{i t}=\frac{\max _{t} x_{i t}-x_{i t}}{\max _{t} x_{i t}-\min _{t} x_{i t}} ;
$$

- obliczanie odległości euklidesowych elastyczności w roku $t$ od wzorca $Z^{+}=(1,1, \ldots, 1)$ oraz od antywzorca rozwoju, $Z^{-}=(0,0, \ldots, 0)$ według wzorów:

$$
\begin{aligned}
& d_{t}^{+}=\sqrt{\sum_{i=1}^{m}\left(z_{i t}-z_{i}^{+}\right)^{2}} ; \\
& d_{t}^{-}=\sqrt{\sum_{i=1}^{m}\left(z_{i t}-z_{i}^{-}\right)^{2}} ;
\end{aligned}
$$

- wyznaczenie syntetycznego miernika elastyczności rynku pracy według wzoru:

$$
m_{t}=\frac{d_{t}^{-}}{d_{t}^{-}+d_{t}^{+}}
$$

Wartości miernika syntetycznego $m_{t} \in[0 ; 1]$, wysokie wartości tego miernika świadczą o wysokiej elastyczności rynku pracy. Obserwacja wartości $m_{t}$ w czasie pozwala na ocenę zmian elastyczności rynku pracy w badanym okresie.

W celu wyznaczania wartości taksonomicznej miary rozwoju Z. Hellwiga normalizację poszczególnych indykatorów elastyczności rynku pracy $X_{i t}$ przeprowadza się, standaryzując ich wartości. Wzorcem rozwoju jest zbiór maksymalnych wartości stymulant oraz minimalnych wartości destymulant. Antywzorzec tworzą wartości przeciwne - minimalne stymulant i maksymalne destymulant.

Miara rozwoju Hellwiga dana jest wzorem:

$$
m_{t H}=1-\frac{d_{t}^{+}}{d_{0}}
$$

gdzie:

$d_{t}^{+}$- odległość badanego zjawiska od wzorca rozwoju w roku $t$,

$d_{0}=\bar{d}+2 s_{0}, \bar{d}=\sum_{t=1}^{n} d_{t}^{+}, s_{0}=\frac{1}{n} \sum_{t=1}^{n}\left(d_{t}^{+}-\bar{d}\right)^{2}$.

Wartości syntetycznej miary rozwoju $m_{t H} \in[0 ; 1]$, wysokie wartości tego miernika świadczą o wysokiej elastyczności rynku pracy.

Jednym z celów prezentowanego badania było poznanie zmian w skali elastyczności polskiego rynku w czasie. Badanie dynamiki obiektów wielocechowych można przeprowadzić za pomocą wielu metod (por. np. [Melich 1994]). W tym przypadku wybrano prostą metodę syntetycznej miary dynamiki, nawiązującą do dwóch poprzednio przedstawionych.

Obliczanie wartości syntetycznej miary dynamiki wymaga na wstępie: standaryzacji wskaźników elastyczności oraz przekształcenia destymulant w stymulanty. 
Następnie konstruuje się dynamiczny wzorzec rozwoju składający się z wartości stymulant z okresu pierwszego, czyli:

$$
Z_{1}=\left(Z_{11}, Z_{21}, \ldots, Z_{i 1}, \ldots, Z_{m 1}\right),
$$

gdzie: $Z_{i 1}$ - wartość $i$-tego wskaźnika elastyczności (stymulanty) w pierwszym $\mathrm{z}$ analizowanych okresów $i=1,2, \ldots, n$.

Syntetyczna miara dynamiki została skonstruowana $\mathrm{z}$ wykorzystaniem reguły indeksu o podstawie stałej, z okresu pierwszego, i obliczana jest jako odległość euklidesowa od wzorca $Z_{1}$ dla każdego okresu objętego badaniem, czyli:

$$
m_{t D}=d_{t}^{1}=\sqrt{\sum_{i=1}^{m}\left(z_{i t}-z_{i 1}\right)^{2}},
$$

gdzie: $d_{t}^{1}$ - odleglość zestandaryzownych wartości wskaźników elastyczności $\mathrm{w}$ okresie $t$ od wartości z okresu pierwszego (wzorca dynamiczego).

Badaniem objęto 10 cech charakteryzujących elastyczność polskiego rynku pracy w latach 2002-2012. Cechy te zostały zaproponowane przez A. Ertman [2011], która badała elastyczność rynków pracy w wybranych krajach europejskich i w USA. Przyjęcie tego samego zestawu zmiennych pozwoliło na porównanie wyników.

Wskaźniki cząstkowe elastyczności rynku pracy:

$X_{1}$ - wskaźnik ochrony zatrudnienia - zatrudnienie tymczasowe (D),

$X_{2}$ - wskaźnik ochrony zatrudnienia - zwolnienia grupowe (D),

$X_{3}-$ klin podatkowy $(\mathrm{D})$,

$X_{4}$ - zasięg związków zawodowych w gospodarce (D),

$X_{5}$ - odsetek pracowników, którzy pracują mniej niż zwykle z powodu „martwego sezonu”, przerw w zakładzie lub z powodów technicznych (S),

$X_{6}$ - odsetek zatrudnionych z umową na czas określony w zatrudnieniu ogółem (S),

$X_{7}$ - bezrobocie długookresowe jako procent ludności aktywnej zawodowo (D),

$X_{8}$ - stopa zatrudnienia starszych pracowników w wieku 55-64 lata (S),

$X_{9}$ - odsetek zatrudnionych w niepełnym wymiarze czasu pracy w ogólnym zatrudnieniu (S),

$X_{10}$ - stopa zatrudnienia wśród osób w wieku poniżej 25 lat (S), gdzie:

$\mathrm{S}$ - stymulanta,

D - destymulanta 2 .

Wartości pierwszych dwóch wskaźników (ochrony zatrudnienia; $X_{1}$ i $X_{2}$ ) charakteryzowały się niewielką zmiennością. W ostatnich latach wzrósł udział zatrudnionych tymczasowo a wskaźnik zwolnień grupowych utrzymuje się na

${ }^{2}$ Wszystkie wykorzystane w badaniu dane (przeliczone i skorygowane w styczniu 2014 r.) pochodzą z następujących źródeł: http://stats.oecd.org/OECDStat_Metadata, http://epp.eurostat. ec.europa.eu. 
prawie stałym poziomie. Klin podatkowy w latach 2002-2008 kształtował się na poziomie 38-39\%, a następnie wykazywał tendencję spadkową do poziomu 35,5\%. W badanym okresie udział związków zawodowych $\left(X_{4}\right)$ w gospodarce wykazywał tendencję wzrostową do 21,5\% w 2006 r., a następnie malejącą do $15 \%$ w 2012 r. Wartości $X_{5}$ (odsetek pracowników sezonowych) wahały się nieregularnie od 0,16\% w 2007 r. do $0,38 \%$ w 2009 r. Natomiast zmienna $X_{6}$ (odsetek zatrudnionych na czas określony w zatrudnieniu ogółem) wykazywała tendencję rosnącą od $15 \%$ w 2002 r. do $27 \%$ w 2012 r. Udział liczby bezrobotnych długookresowo w populacji osób aktywnych zawodowo $\left(X_{7}\right)$ malał znacząco do 2008 r., a następnie zaobserwowano niewielki wzrost do wartości 4,1\% w $2012 \mathrm{r}$. Udział pracujących w wieku przed i okołoemerytalnym w Polsce $\left(X_{8}\right)$ w latach 2002-2012 wzrastał od 28\% do około $39 \%$. Zmienna $\left(X_{9}\right)$ reprezentująca odsetek zatrudnionych w niepełnym wymiarze czasu pracy w ogólnym zatrudnieniu wykazywała niewielki spadek wartości od 10,8\% w 2002 r. do 7,9\% w 2012 r. Stopa zatrudnienia wśród osób w wieku poniżej 25 lat $\left(X_{10}\right)$ średnio kształtowała się na poziomie około $24 \%$, wykazywała wzrost w okresie do 2008 r. do wartości $27,3 \%$ i niewielki spadek do poziomu przeciętnego $\mathrm{w}$ ostatnim obserwowanym roku.

\section{Wyniki badania}

Wartości wszystkich trzech syntetycznych miar elastyczności zamieszczone zostały w tabeli 1 .

Tabela 1. Wartości syntetycznych mierników elastyczności rynku pracy

\begin{tabular}{|c|c|c|c|}
\hline Rok & $m_{t}$ & $m_{t H}$ & $m_{t D}$ \\
\hline 2002 & 0,352 & 0,108 & - \\
\hline 2003 & 0,365 & 0,143 & 2,413 \\
\hline 2004 & 0,376 & 0,146 & 3,970 \\
\hline 2005 & 0,387 & 0,163 & 4,617 \\
\hline 2006 & 0,365 & 0,117 & 5,725 \\
\hline 2007 & 0,501 & 0,211 & 6,294 \\
\hline 2008 & 0,664 & 0,333 & 6,644 \\
\hline 2009 & 0,754 & 0,449 & 6,125 \\
\hline 2010 & 0,748 & 0,452 & 6,304 \\
\hline 2011 & 0,691 & 0,383 & 6,660 \\
\hline 2012 & 0,666 & 0,373 & 6,648 \\
\hline
\end{tabular}

Źródło: opracowanie własne. 


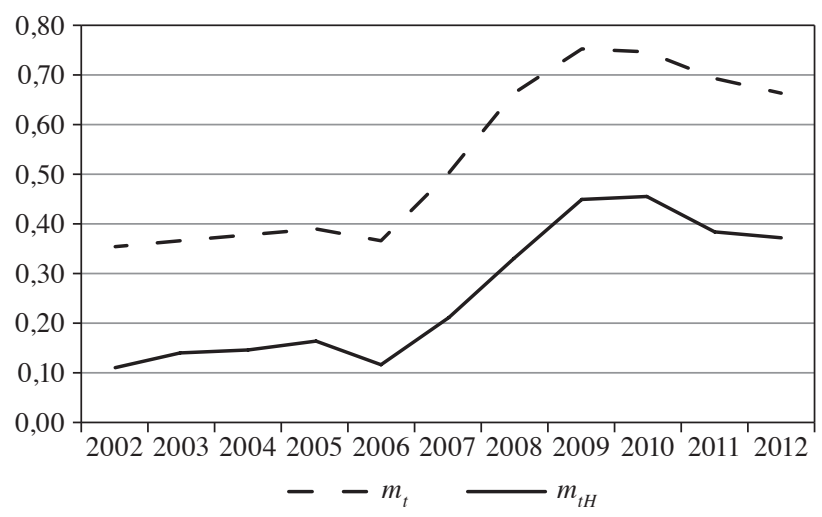

Rys. 1. Wartości miar elastyczności rynku pracy $-m_{t}$ i $m_{t H}$ Źródło: opracowanie własne.

Z przeprowadzonych badań wynika, że stopień deregulacji polskiego rynku pracy wzrastał do $2009 \mathrm{r}$. według miary $m_{t}$ i do $2010 \mathrm{r}$. według miary $m_{t H}$, po czym powoli zaczął maleć. Z kolei według miary $m_{t D}$ maksymalny, w stosunku do poziomu z 2002 r., stopień elastyczności rynku pracy miał miejsce w latach 2008 i 2011.

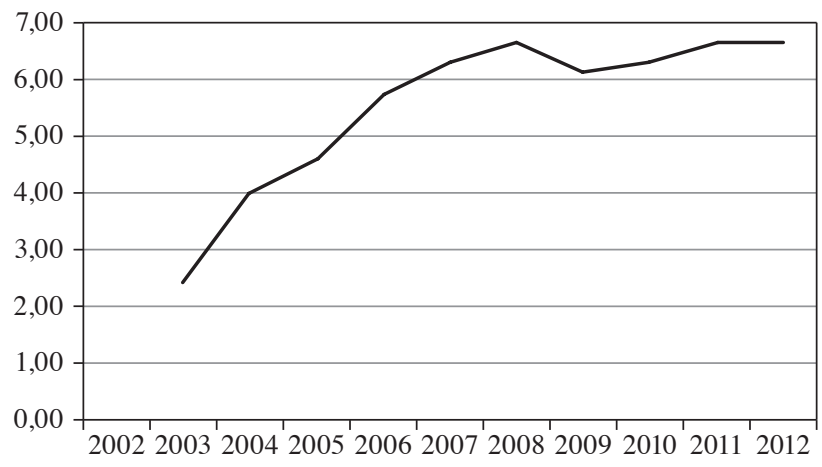

Rys. 2. Wartości miary $m_{t D}$

Źródło: opracowanie własne.

Wartości miar $m_{t}$, i $m_{t H}$ wykazywały jednakowe tendencje zmian, choć wartości drugiej z nich charakteryzowały się większą zmiennością. Również i wartości miary $m_{t D}$ potwierdzają wzrostową tendencję deregulacji rynku pracy 
w Polsce. $Z$ danych zamieszczonych w tabeli 1 i na rys. 2 wynika, że jej wartości silnie wzrastały, osiągając wartość maksymalną w 2008 r. podobnie jak wartości poprzednich dwóch miar. Kształtowanie się wartości miar syntetycznie opisujących badane zjawisko ilustrują wykresy zamieszczone na rys. 1 i 2.

Podsumowując uzyskane wyniki, można stwierdzić, że została potwierdzona hipoteza, że polski rynek pracy staje się coraz bardziej elastyczny. W okresie spowolnienia gospodarki w latach 2008-2009 zaobserwowano najwyższy stopień deregulacji rynku pracy (mierzony za pomocą zastosowanych miar), co można traktować jako przejaw działania mechanizmów obronnych działających na tym rynku.

\section{Uwagi końcowe}

Rozważany problem ma bardzo istotne znaczenie zarówno teoretyczne, jak i praktyczne. Współczesne rynki pracy wymagają pewnego zakresu deregulacji, kwestią dyskusyjną pozostaje nadal jej stopień. Problem wyboru między regulacją a deregulacją rynku pracy jest odwiecznym, jak twierdzi Z. Wiśniewski [2004, s. 294], problemem zarówno teoretyków, jak i praktyków gospodarczych. Wśród ekonomistów od lat trwa dyskusja na temat skali regulacji bądź deregulacji rynku pracy jako elementu ogólnej polityki rynku pracy. Przeciwstawia się europejskie na ogół bardziej regulowane (oprócz Wielkiej Brytanii) rynki, rynkowi Stanów Zjednoczonych, który charakteryzuje się najwyższym stopniem deregulacji wśród krajów OECD i jednocześnie najniższym poziomem bezrobocia [Wiśniewski 2004, s. 295]. Jednym z proponowanych rozwiązań problemu, jak pogodzić czy wręcz zrównoważyć elastyczność z bezpieczeństwem rynku pracy, jest koncepcja flexicurity, która zakłada $\mathrm{z}$ jednej strony wspieranie elastycznego rynku, a z drugiej zachowanie wysokiego poziomu zabezpieczenia społecznego.

Warto w tym miejscu dodać, że z badań porównawczych A. Ertman [2011] oraz z badań autorek niniejszego opracowania wynika, że polski rynek na tle wybranych rynków europejskich charakteryzuje się przeciętnym poziomem elastyczności oraz że elastyczność ta wykazuje tendencję wzrostową, co zostało potwierdzone wynikami badań.

Podjęty w artykule problem wymaga dalszych szczegółowych analiz, np. dokładnych badań poszczególnych indykatorów elastyczności rynku pracy, czyli elastyczności cząstkowych. Jednym z najważniejszych jest tzw. klin podatkowy, który ma negatywny wpływ na sytuację na rynku pracy. W warunkach polskich w latach 2000-2012 klin podatkowy kształtował się na poziomie 34-39\%, a w krajach o wysokiej elastyczności rynku pracy poziom klina podatkowego jest zdecydowanie niższy. Na uwagę w omawianym kontekście zasługują też takie 
problemy, jak: pozycja związków zawodowych w gospodarce, umowy na czas określony, zatrudnianie ludzi w wieku emerytalnym.

\section{Literatura}

Bartosik K. [2012], Popytowe i podażowe uwarunkowania polskiego bezrobocia, „Gospodarka Narodowa" nr 11-12.

Elastyczność polskiego rynku pracy [w:] Elastyczny rynek pracy w Polsce. Jak sprostać temu wyzwaniu? [2004], red. M. Boni, Zeszyty BRE Bank - CASE nr 73, CASECentrum Analiz Społeczno-Ekonomicznych, Fundacja Naukowa, Warszawa.

Ertman A. [2011], Zróżnicowanie elastyczności rynków pracy w wybranych krajach europejskich oraz USA w świetle metody TOPSIS, Oeconomia Copernicana, nr 3.

Giegiel A. [2007], Elastyczność rynku pracy a dynamika wzrostu gospodarczego w wybranych krajach OECD [w:] Wykorzystanie zasobów pracy we współczesnej gospodarce, red. D. Kopycińska, Wydawnictwo PRINT GROUP Daniel Krzanowski, Szczecin.

Góra M. [2003], Wpływ systemu zabezpieczenia społecznego na rynek pracy, „Ekonomista", nr 1.

Kwiatkowski E. [2003], Elastyczność popytu na pracę w teoriach rynku pracy [w:] Elastyczne formy zatrudnienia i organizacji pracy a popyt na prace $w$ Polsce, red. E. Kryńska, IPiSS, Warszawa.

Melich K. [1994], Kilka uwag na temat dynamicznej analizy obiektywnej jakości życia [w:] Ekonometria, Materiały z XXVIII Konferencji Ekonometrycznej i X Seminarium Naukowego im. Zbigniewa Pawłowskiego, Akademia Ekonomiczna w Katowicach, Katowice-Kraków-Wrocław.

Skórska A. [2007], Przeciwdziałanie bezrobociu [w:] Ekonomia rynku pracy, red. D. Kotlorz, Wydawnictwo Akademii Ekonomicznej w Katowicach, Katowice.

Sobocka-Szczapa H. [2003], Nietypowe formy zatrudnienia pracowniczego [w:] Elastyczne formy zatrudnienia $i$ organizacji pracy a popyt na prace $w$ Polsce, red. E. Kryńska, IPiSS, Warszawa.

Wiśniewski Z. [2004], Rynki pracy w przyszłości - deregulacja a zatrudnienie [w:] Przyszłość pracy w XXI wieku, red. S. Borkowska, IPiSS, Warszawa.

\section{Elasticity of the Polish Labour Market - a Dynamic Analysis}

(Abstract)

The paper looks at the elasticity of the Polish labour market in the years 2002-2012. It first discusses the notion and role of labour market deregulation in the contemporary economy. It goes on to examine the scale and dynamics of the elasticity of the Polish labour market, described with 10 fragmentary indicators. Research was conducted with three synthetic measures and changes in their value in time were compared.

Keywords: labour market, labour market elasticity, synthetic measures, development indices. 